Arch. Tierz., Dummerstorf 47 (2004) 6, 517-535

Institute for Animal Breeding and Genetics, University of Veterinary Medicine Hannover

KERSTIN S. ABERLE and OTTMAR DISTL

\title{
Domestication of the horse: results based on microsatellite and mitochondrial DNA markers
}

Dedicated to Prof. Dr. habil. Peter Glodek on the occasion of his $70^{\text {th }}$ birthday

\begin{abstract}
Many horse populations suffered severe decreases in numbers in the last century; some, such as the Coldblood horse breeds drastically declined in their population size, while others could be saved at the last minute. It is important to evaluate the amount of genetic variability still present in those populations in order to develop conservation programmes. Furthermore, it is essential to construct phylogenetic trees and to establish the relationships among different horse populations in order to deepen our understanding of the evolution and domestication of the horse. In the past ten years microsatellite markers have been widely used to assess genetic variability within and between different horse breeds. Moreover, attempts have been made to evaluate the phylogenetic relationships of different horse breeds by comparing mitochondrial DNA (mtDNA) sequences. In this paper we give an overview of the latest major findings in studies based on horse microsatellite data and mitochondrial DNA sequences.
\end{abstract}

Key Words: horse, microsatellites, mitochondrial DNA, genetic diversity

\section{Zusammenfassung}

Titel der Arbeit: Domestikation des Pferdes: Ergebnisse von Mikrosatelliten- und mitochondrialen DNA Markern

Viele Pferdepopulationen, insbesondere Kaltblutpferderassen, gingen in ihren Bestandszahlen in den letzten Jahrzehnten drastisch zurück. Viele Kaltblutrassen konnten jedoch erhalten werden, wobei für manche Rassen die Rettung erst in letzter Minute möglich war. Für Erhaltungsprogramme ist es wichtig, die Höhe der noch vorhandenen genetischen Variabilität in solchen Populationen zu quantifizieren und die phylogenetische Beziehung zu anderen Rassen zu kennen. Damit kann der Wert der Rasse in ihrer Bedeutung für die Evolution and Domestikation der Pferde eingeordnet werden. Vorwiegend in letzten zehn Jahren wurden Studien mit Mikrosatellitenmarkern durchgeführt, um die genetische Variabilität innerhalb und zwischen den verschiedenen Pferderassen zu schätzen. Darüberhinaus wurde versucht, mittels mitochondrialer DNA (mtDNA) Sequenzen die phylogenetische Beziehung zwischen den verschiedenen Pferderassen aufzuklären. In dieser Arbeit wird ein Überblick über die Ergebnisse von Mikrosatelliten- und mitochondrialen DNA Sequenzstudien gegeben.

Schlüsselwörter: Pferd, Mikrosatellitenmarker, mitochondriale DNA, genetische Diversität

\section{Introduction}

The animals thought to be wild ancestors of today's domestic horses are extinct in nature and most of the species' genome is currently maintained in the different breeds of domesticated horses (SPONENBERG, 2000). For thousands of years the horse was an essential component of economic production until suddenly, at the end of the $19^{\text {th }}$ century, a turning point was reached, when the horse lost its importance for riding, transportation of goods and men, or as a draught animal in most parts of the world. Today the horse is chiefly used in leisure activities and sports. Draught horses and 
horses that do not conform to the image of a modern riding horse are especially affected by this situation.

As populations decline, rare specific genetic material is lost, leading to decrease genetic diversity, and if these breeds even become extinct, there is no possibility for future generations to refer back to these horses and their unique gene pool. Finally, it should not be forgotten that horses were integral to the distribution of peoples in the world today, by enhancing human mobility and making it possible for humans to exploit various regions of the world in ways that would otherwise have been impossible (BÖKÖNYI, 1987).

Comparison of the genetic structure of different breeds reveals the genetic distances among them, which in turn deepens our understanding of the development of today's horse breeds. Today's common warmblood or standardbred race horse populations are composites of many different breeds from all over the world. In contrast, there have been little gene flows among draught horses from different parts of Europe and pony breeds often still present morphological characteristics comparable to those found in wild horses. These characteristics include dun colour with a two-coloured mane, back stripes and in some cases leg stripes and lighter parts around eyes and muzzle, as seen for example in the Fjord Horse of Norway or in certain pony breeds in the UK. But most of today's pony breeds have been crossed with Arabian or Thoroughbred horses to obtain small riding horses with some of the characteristics of warm-blooded horses. Therefore, only the gene pool of the primitive ancestors of today's riding horses, which still do exist in some regions, and these last extant wild horse, the Przewalski's Horse, can help us to understand the development of today's horse breeds and how domestication took place.

Examples of different horse populations discussed in this paper are the recently bottlenecked draught horse, and certain primitive and wild horse breeds. Most of these breeds are still rare and consequently considered endangered by the FAO (http://dad.fao.org/en/home.htm) and EAAP-AGDB (http://www.tihohannover/einricht/zucht/eaap/index.htm). Herein, we show genetic methods for assessing genetic diversity and how they can enhance our understanding of horse phylogeny and domestication. Furthermore, we discuss the genetic relationships among Przewalski’s and Sorraia horse breeds and today's domestic horses.

Primitive and wild horses - once almost extinct

There is no official definition for the term "primitive horse", but it is usually used for autochthonic horse breeds such as the Exmoor Pony and the Sorraia Horse, which are considered to be progenitors to local domestic breeds. Many of these primitive breeds were nearly extinct at the beginning of the $20^{\text {th }}$ century. They are culturally important for the history of today's domestic horse breeds.

\section{Exmoor Pony}

The Exmoor Pony is one of the oldest known types of horses found in the United Kingdom. Comparisons of osteological discoveries dated between 12,000 and 120,000 years ago with Exmoor Pony skeletons revealed almost no morphological differences (NISSEN, 1998). All attempts to improve the breed have failed, because the hybrids were not able to survive in the harsh area of wild Exmoor (NISSEN, 1998). In 1899 the Exmoor Division of the National Pony Society was founded, and 22 years later the 
Exmoor Pony Society was established with the main objective to save this old breed as purebred (SAMBRAUS, 2001; NISSEN, 1998). The Exmoor Pony population has always been quite small, but it decreased to about only 50 individuals after World War II. Today the population consists of about 390 mares and 63 stallions and is considered critical-maintained by the FAO. Exmoor Ponies are bay, brown or dun in colour, with no white markings; they may have mealy patches on muzzle, belly, and around the eyes. Adult males and females weigh on average $227 \mathrm{~kg}$ with an average withers height of $130 \mathrm{~cm}$.

\section{Sorraia Horse}

The Sorraia Horse from the South of the Iberian Peninsula is considered a primitive horse breed and is believed to be an ancestor of the Andalusian and Lusitano horse breeds (OOM and COTHRAN, 1994). The Sorraia has always been the herdsman's horse of the Portuguese Vaqueros and was known for its good adaptation to harsh conditions (NISSEN, 1998). It was recovered from twelve founder animals by Dr. Ruy d'Andrade in 1937. In 1975 the German ethologist Dr. Michael Schäfer founded a population in Germany on the basis of six original Sorraia Horses with no further immigration. The population today is represented by fewer than 150 animals (101 from Portugal and 47 from Germany; OOM and LUÍS, 2001).

Sorraia are mouse colour or yellow dun with a dorsal stripe and zebra-striped legs (Tarpan-like). Adult males weigh on average $400 \mathrm{~kg}$ and females $350 \mathrm{~kg}$, with an average withers height of $145 \mathrm{~cm}$ and $140 \mathrm{~cm}$, respectively.

\section{Przewalski's Horse}

These horses are descended from the wild Equus ferus przewalskii Poliakov in Central Asia, which was "discovered" by the Polish Colonel Przewalski in 1878 (BOUMAN, 1994). It is the only extant species of true horse other than the domestic horse, $E$. caballus. In 1969, the Mongolian scientist N. Dovchin was the last person to see a Przewalski's Horse in the wild (BOUMAN, 1994), but the species has been maintained in captivity. Today's captive population is entirely descended from 13 individuals caught in the wild. One of these females is considered to have been a domestic Mongolian mare and another a domestic/Przewalski's hybrid (OAKENFULL and RYDER, 1998). The last founder mare caught in the wild entered the pedigree in 1947, and was sold to Askania Nova in the Ukraine ten years later, where the most important of the captive herds is maintained under semi-domestic conditions (BOUMAN, 1994). The chromosome number of Przewalski's Horses is $2 \mathrm{n}=66$, whereas that of domestic horses is $2 n=64$ (BENIRSCHKE et al., 1965). However, the genetic material is so similar that hybrids are fertile (RYDER et al., 1978). There are about 1,000 (VOLF, 1996) individuals of this species today, which is still considered endangered by the FAO.

The coat colour is red-brown with light underparts, muzzle and the region round the eyes. Typical for the Przewalski's Horse are black back-stripes and leg stripes; in some cases dark cross-stripes near the tip of the mane; and an erect mane (GROVES, 1994). Adult horses weigh about between 240 and $300 \mathrm{~kg}$ with a withers height of about 130 to $145 \mathrm{~cm}$ (VOLF, 1995). 
Microsatellites and their requirements for genetic diversity studies

Most measurements of genetic diversity are based on variants in the DNA sequence found between different breeds, populations or animals. Such genetic markers generally have no known function and evolve rapidly, so that differences can be observed between closely related breeds. Microsatellites are currently the most commonly used markers for diversity studies in livestock. They have at their core a short DNA sequence of between two and ten basepair repeats which are variable in number and thus in length. The number of length polymorphisms of a microsatellite is equivalent to the number of its alleles. Most microsatellites are multiallelic. Microsatellites were first characterised in horses by ELLEGREN et al. (1992) and MARKLUND et al. (1994). Originally microsatellites were chiefly used for parentage analysis. Later, various methods were applied to microsatellite data for the estimation of phylogenetic relationships. The main drawback of this type of marker for the study of diversity is the lack of comparability between studies. For a comparison of different studies one must select the same, technically robust microsatellite markers, and reference samples must be used in all studies. Once genetic marker data has been collected, diversity within a single population is quantified by means of simple statistics including the average number of different alleles present at marker loci and the average heterozygosity in the population. Differences between populations are usually summarised by measures of genetic distances. These generally agree with similarity in allele frequencies between two populations, with maximisation of a large distance when the two populations have completely different alleles. The most often used way to visualise the pairwise distances is in the form of a tree, or dendrogram, where the relative lengths of the branches correspond to the genetic distances among breeds.

The FAO proposed a set of microsatellite loci for different livestock species as standard for assessing genetic distances. The use of 25 different microsatellite loci was suggested. The main recommendations were that microsatellites should be in the public domain, preferably unlinked, their variants should follow Mendelian inheritance, and each microsatellite locus should exhibit at least four alleles. Furthermore, microsatellite loci with high heterozygosity values should be preferred as they considerably increase the possible amount of variability. Unfortunately, there is as yet no generally defined microsatellite set for horses, although many data on genetic diversity in horses have been published.

Genetic diversity within the Przewalski's wild Horse and the Sorraia Horse breed BREEN et al. (1994) demonstrated that microsatellites isolated from the horse frequently amplified polymorphic sequences in the other species of the genus. The level of polymorphism of the Przewalski's Horse was comparable to that in the mixed group of domestic horses, although some alleles appeared to be present in the wild species, but not in domestic horses.

Since two populations of Sorraia Horses exist in Europe without known gene flow, the difference in genetic variation within the Sorraia Horse breed of the Portuguese and German subpopulations is of primary interest for the development of conservation strategies. Comparing the subpopulations to each other, OOM and LUÍS (2001) found that two of the Sorraia founders are no longer represented in the living population and that some under-represented founders are at great risk of loss. The German 
subpopulation contained few alleles per locus due to founder effects, although no alleles have been lost by genetic drift. However, the levels of heterozygosity in the German subpopulation were found to be higher than in the Portuguese population due to the mating strategy practiced in Germany of using more than one stallion per breeding year. Thus, the investigators concluded that the subdivision of small and closed populations followed by further immigration between subpopulations would be a useful tool for genetic conservation.

The relationship of Spanish Celtic horse breeds to different pony breeds and to the Uruguayan Creole Horse

Genetic distances within a small Celtic pony breed were compared to results obtained by BREEN et al. (1994). CHECA et al. (1998) found most of the alleles already described by BREEN et al. (1994), proving the comparability of populations in different studies when similar sampling procedures are used. Nine of the microsatellite markers they used were recommended for parentage analysis (BINNS et al., 1999). The problem with these markers is that three marker pairs are mapped to the same chromosome, so there is a slight danger that these markers might not segregate completely independently (SHIUE et al., 1999; BINNS et al., 1999). Nevertheless, CHECA et al. (1998) recorded a high proximity of the two Spanish pony breeds studied with the mixed domestic horse group and therefore assumed that the Shetland and New Forest Pony probably had common ancestors with the Spanish Celtic pony breeds. In addition to these Spanish breeds, CAÑON et al. (2000) included six more Spanish Celtic horse breeds from different areas and compared them to a group of thoroughbreds. CAÑON et al. (2000) used the same marker set as CHECA et al. (1998) with two additional markers. They discovered higher heterozygosity level and mean number of alleles in the Spanish Atlantic breeds than in the Balearic Island breeds. Both breeds clearly formed separate clusters. Furthermore, Asturcon, Losina and Balearic breeds were clearly separate from each other and from the remaining breeds, which were not consistently differentiated.

KELLY et al. (2002) used nine microsatellite markers recommended for parentage analysis in addition to seven blood groups and nine protein polymorphism loci to evaluate genetic variability within the Uruguayan Creole Horse and its relationship to a group of geographically or historically related breeds. The results lend support to the hypothesis that the Creole Horse has conserved its genetic potential from the ancient Spanish Horse, which was more similar to the Barb than to the present-day Spanish purebred horses, since a cluster was formed by American horse breeds together with Barb and Arabian Horses which is clearly separate from the modern Spanish purebred and thoroughbred breeds.

Genetic distances of some native, warm-blooded and cold-blooded horse breeds and Thoroughbreds

BJØRNSTAD et al. (2000) investigated the genetic structure of four native Norwegian horse breeds using microsatellites and biochemical loci. They used ten microsatellite markers recommended for parentage testing by the ISAG and 16 additional microsatellite loci. They measured genetic variation such as heterozygosity and the number of alleles and found indication of high variation in the Fjord Horse and the Coldblooded Trotter, but a somewhat reduced variation in the Døle Horse. They 
detected significant population differentiation among all breeds, including the recently diverged Døle Horse and Coldblooded Trotter. As expected they also observed reasonably close associations between the reference populations of Thoroughbreds and Standardbreds. CUNNINGHAM et al. (2001) used nine of the parentage analysis microsatellites to assess genetic diversity in Thoroughbreds, and they added four different loci. They estimated relationships on the basis of shared alleles and shared ancestry. Both measurements were shown to be closely related and when combined revealed the genetic variation which was present in the founder animals. These analyses confirmed the narrow genetic base of this breed and provided comprehensive information on the contributions of founder animals.

\section{German Coldblood horse breeds}

Unlike warmblood horses and thoroughbreds, draught horses are even-tempered, heavily muscled, strong working horses. In fact, controlled breeding of heavy draught horse breeds as we know them in Germany today did not start before the late $19^{\text {th }}$ century (SCHARNHÖLZ, 2002). However, intensification of agriculture and the onset of industrialisation at the end of the $19^{\text {th }}$ century led to an urgent demand for these breeds, resulting in rapidly increasing population sizes after 1900 until 1950. Nevertheless, a few decades later heavy draught horses had become increasingly unimportant due to the intense mechanisation of agriculture and transport systems, and the populations decreased to alarmingly low numbers in the 1970s. Fortunately, governmental support and the dedication of horse breeders helped to save these culturally important breeds from extinction.

\section{South German Coldblood}

The South German Coldblood can be traced back to local horse populations in the former Roman province Noricum in Austria and Bavaria. First certain written evidence of horse breeding in the Pinzgau area dates back to the $16^{\text {th }}$ century (SCHARNHÖLZ, 2002). At the end of the $19^{\text {th }}$ century, there were two different subpopulations the lighter Oberländer and the heavier Pinzgauer (KARNBAUM, 1997). The first studbook for Pinzgauers appeared in 1903 (SCHARNHÖLZ, 2002). In 1927 the Austrian-Bavarian federation for Noric Horse breeding was created, and the Bavarian and Austrian populations were merged as a single Noric breed. After 1945 the Bavarian Noric horses became "South German Coldbloods". But the South German Coldblood was not spared the consequences of motorisation of agriculture and transport systems, and there were only 568 registered mares in 1976. There was an upward trend shortly afterwards due to the dedication of the Bavarian horse breeders and to national campaigns which resulted in the South German Coldblood population becoming Germany's largest heavy draught horse population today with 2001 mares, 109 stallions and an effective population size $\left(\mathrm{N}_{\mathrm{e}}\right)$ of 413 (DISTL and WREDE, 2002). The coat colour of this breed is predominantly chestnut with a light mane. Adult horses weigh on average between 700 and $900 \mathrm{~kg}$ with an average withers height of between 158 and $164 \mathrm{~cm}$ (SAMBRAUS, 2001).

\section{Rhenish German Draught Horse}

The oldest known breeding area of the breed formerly called Rhenish Belgian, later named the Rhenish German Horse, was Northern Rhenish Prussia, which later became the Rhenish province of the federal state of Northern Rheinland-Westphalia 
(SCHARNHÖLZ, 2002). The studbook of this breed, which descended from Belgian Draught Horses, was established in 1892. The East German Altmaerkisch, Mecklenburg, and Saxon Thuringa Coldblood breeds were developed from the Rhenish German Draught Horse, but these breeds were isolated for four decades due to the political division of Germany. These horses are bred in Thuringa and Saxony (Saxon Thuringa Coldblood), in Western Pomerania, and Mecklenburg (Mecklenburg Coldblood), and in Saxony-Anhalt and Brandenburg (Altmaerkisch Coldblood).

In 1946 the population of registered Rhenish German Draught horses peaked at 25,022 horses (SCHARNHÖLZ, 2002). In the 1970s only a few hundred horses were registered in both the West German and East German populations.

Today the Rhenish German population comprises 767 mares and 83 stallions $\left(\mathrm{N}_{\mathrm{e}}=\right.$ 300; DISTL and WREDE, 2002) and is still registered by the FAO as an endangered breed. The largest East German population is the Saxon Thuringa Coldblood (327 mares, 31 stallions; $\mathrm{N}_{\mathrm{e}}=113$; DISTL and WREDE, 2002), and the other two populations comprise between 130 and 140 horses, with an effective population size of 36 (Mecklenburg) and 60 (Altmaerkisch). Adult mares have an average withers height of $160 \mathrm{~cm}$, adult stallions about $165 \mathrm{~cm}$, and weigh up to $1000 \mathrm{~kg}$ (SAMBRAUS, 2001). East German horses are usually smaller than the West German.

\section{Black Forest Horse}

The earliest indications of local horse breeding in the Black Forest area were found in the archives of several local cloisters and can be traced back to the beginning of the 15th century (FREY, 1984; SCHARNHÖLZ, 2002). The "Waelderpferd" of Black Forest farmers was heavily influenced by several wars which lasted centuries, during which Spanish, French, Croatian, and Russian regiments wandered through the Black Forest area (FREY, 1984). Genealogically the Black Forest horse belongs to the Noric Horse group. The studbook was established in 1896. After 1945 there were 1,234 mares registered in the studbooks. This number decreased in 1977 to the all-time low (159 mares; WEBER, 2001), as was the case for the other heavy horse breeds at that time. Today the population consists of 750 mares and 49 stallions $\left(\mathrm{N}_{\mathrm{e}}=184\right.$; DISTL and WREDE, 2002) and is considered endangered by the FAO.

Black Forest Horses are dark-chestnut or rarely bay in colour with a light mane. Adult males weigh on average $680 \mathrm{~kg}$ and females $610 \mathrm{~kg}$, with an average withers height of $156 \mathrm{~cm}$ and $152 \mathrm{~cm}$, respectively.

\section{Schleswig Draught Horse}

The Schleswig Draught Horse was developed from the "Bauernlandpferd“ and Jutland Coldblood with some further input from Danish Jutland Coldblood. Before 1862, when a draught horse stallion was imported from England, efforts were made to improve the local working horses with British Yorkshire stallions (SCHARNHÖLZ, 2002). There has been a studbook for this breed since 1892. Despite considerably large populations up to 1950 (14,500 breeders and more than 32,000 mated mares in 1948; NISSEN, 1997), the Schleswig Draught Horse decreased to its lowest numbers of 60 registered mares in 1976 and today represents Germany's smallest heavy horse population (206 mares, 26 stallions; $\mathrm{N}_{\mathrm{e}}=89$; DISTL and WREDE, 2002). It therefore is considered endangered by the FAO. The horses are primarily chestnut in colour, but they also may be black, bay or grey (SCHARNHÖLZ, 2002). Adult horses weigh on 
average $800 \mathrm{~kg}$, with an average withers height of between 156 and $162 \mathrm{~cm}$ (SAMBRAUS, 2001).

Genetic diversity among German coldblood breeds

We compared the genetic diversity and relationships among six German heavy draught horse breeds to six wild, primitive, or riding horse breeds by means of genotypic information from 31 microsatellite loci distributed over all autosomes. Blood or hair root samples were collected from South German Coldblood ( $N=45)$, Rhenish German Draught Horses $(\mathrm{N}=45)$, Saxon Thuringa Coldblood $(\mathrm{N}=23)$, Mecklenburg Coldblood $(\mathrm{N}=22)$, Black Forest $(\mathrm{N}=45)$, and Schleswig Draught Horses $(\mathrm{N}=45)$. To place the results in context with other horse breeds, DNA samples were also analysed from Hanoverian Warmblood ( $\mathrm{N}=47)$, Arabian $(\mathrm{N}=26)$, Sorraia Horses ( $\mathrm{N}$ $=23)$, Icelandic Horses $(\mathrm{N}=45)$, Exmoor Ponies $(\mathrm{N}=20)$, and Przewalski's Horses $(\mathrm{N}=18)$.

\section{Microsatellite amplifications and statistical analysis}

The 31 microsatellites were amplified alone or in multiplexes (two to five co-amplified loci) in eleven independent PCR reactions. Each $12 \mu \mathrm{L}$ PCR reaction tube contained 40ng genomic DNA, $1.2 \mu \mathrm{L}$ 10x PCR buffer, $15 \mathrm{mM} \mathrm{MgCl}_{2}, 0.5 \%$ DMSO, $100 \mu \mathrm{M}$ each dNTP, 0.75 U Taq-Polymerase (Qbiogene, Heidelberg, Germany), 5’ IRD700 or IRD800 labelled forward primer, and unlabelled reverse primer in the amounts indicated in Table 1. The amplification was carried out in PTC- $100^{\mathrm{TM}}$ or PTC-200 ${ }^{\mathrm{TM}}$ thermocyclers (MJ Research, Inc., Watertown, MA, USA) under the following conditions: an initial denaturation step at $94^{\circ} \mathrm{C}$ for 4 min followed by 35 cycles at $94^{\circ} \mathrm{C}$ for $30 \mathrm{~s}$, maximum annealing temperatures for $60 \mathrm{~s}$, and a final extension of $30 \mathrm{~s}$ at $72^{\circ} \mathrm{C}$. The dilution of PCR products with formamide loading dye in ratios from 1:6 to 1:30 was determined empirically and carried out prior to size fractionating on $6 \%$ denaturing polyacrylamide (rotiphorese ${ }^{\circledR} \mathrm{Gel} 40$, Carl Roth, Karlsruhe, Germany) sequencing gels. Gelelectrophoresis was performed on an LI-COR 4200S-2 automated sequencer. Allele size was scored against known samples used as standards on every gel. Raw data were genotyped by visual examination and manual input.

Allele frequencies, unbiased estimates for expected $\left(\mathrm{H}_{\mathrm{E}}\right)$ and observed $\left(\mathrm{H}_{\mathrm{O}}\right)$ heterozygosity, and the number of alleles were computed using MSA (Microsatellite Analyzer, Dieringer \& Schlötterer, 2003). Hardy-Weinberg equilibrium (HWE) tests were conducted with the GENEPOP package version 3.3 (RAYMOND and ROUSSET 1995). Exact P-values were calculated along with their standard errors using GUO and THOMPSON (1992) Markov-Chain algorithm with 1,000 dememorisation steps for 100 batches and 1,000 iterations per batch. A Bonferroni-Holm correction (HOLM 1979) was applied to the exact P-values to maintain a multiple test level. First a correction was performed within each population over all 31 loci, after which the HWE was tested over all population loci combinations. If more than one population locus combination deviated from HWE, this microsatellite marker was not used for calculating genetic distances in order to obtain stable phylogenies with a great number of informative loci, without distorting genetic distances due to the significant deviation from the HWE. Since HMSO3 showed deviations from HWE in more than one population, this locus was excluded from further calculations. 
In addition, the hypothesis was tested that all twelve horse breeds are significantly distinguishable on the basis of genic and genotypic differentiation using GENEPOP. Afterwards differentiation tests were performed between the breeds for each locus to evaluate the significance of genetic differentiation among the populations. Genetic diversity within populations was measured as the mean number of alleles (NA) per locus, the number of private alleles (PA, alleles found in only one breed), the observed heterozygosity $\left(\mathrm{H}_{\mathrm{O}}\right)$, and the expected heterozygosity $\left(\mathrm{H}_{\mathrm{E}}\right)$ under $\mathrm{HWE}$. The average expected heterozygosity for each population $\left(\mathrm{H}_{\mathrm{S}}\right)$, the gene diversity in the total population $\left(\mathrm{H}_{\mathrm{T}}\right)$ and the coefficient of gene differentiation $\mathrm{G}_{\mathrm{ST}}$ (NEI 1973) were estimated separately for the heavy draught horse populations and the other horse populations with the computer programme FSTAT version 2.9.3 (GOUDET 1995). The individual observed heterozygosities were regressed on the individual inbreeding coefficients of the draught horse breeds using the Pearson correlation coefficient.

The chord distance constructed by CAVALLI-SFORZA and EDWARDS (1967) ( $\left.\mathrm{D}_{\mathrm{C}}\right)$ is one of the best qualified for use with populations of intermediate divergence time as represented by breeds worldwide and in the breeds under study (EDING and LAVAL 1999). The neighbour-joining tree topology was obtained with the PHYLIP software version 3.5 (FELSENSTEIN 1989) using the Cavalli-Sforza distance $\mathrm{D}_{\mathrm{C}}$. Bootstrap values were computed over 1,000 replicates, and a consensus tree was drawn. A modified non-linear algorithm was used for the construction of a two-dimensional presentation of genetic distances. The robustness of the classification was tested by bootstrapping and then displayed as confidence circles representing 95\% of the variation observed for each breed. The bootstrapping was performed with 100 samples and a sample size reflecting the real sample size of each breed.

The assignment tests were carried out using the GENECLASS software program version 1.0.02 (CORNUET et al. 1999). The Bayesian option was used to compute the population allele frequencies. Direct and exclusion-simulation tests were carried out among all twelve breeds.

\section{Results and discussion}

The average observed heterozygosity $\left(\mathrm{H}_{\mathrm{O}}\right)$ differed little among the German heavy horse breeds (0.64 to 0.71 ), but was significantly negatively correlated to individual inbreeding coefficients (Table 1). The mean number of alleles (NA) decreased more obviously with declining population size of German draught horse breeds (5.2 to 6.3). The most severe losses in genetic diversity were found in the Sorraia Horse $\left(\mathrm{H}_{\mathrm{O}}=0.53\right.$; $\mathrm{NA}=3.4)$ and the Przewalski's Horse $\left(\mathrm{H}_{\mathrm{O}}=0.47 ; \mathrm{NA}=3.8\right)$. The coefficient of differentiation among the heavy horse breeds showed $11.6 \%$ of the diversity between the heavy horse breeds, as opposed to $21.2 \%$ between the reference populations. The differentiation test revealed significant genetic differences among all breeds except the Mecklenburg and Saxon Thuringa Coldbloods. Heavy horse breeds clearly formed a separate cluster from the reference populations, in which the Rhenish German Draught Horse, Saxon Thuringa and Mecklenburg Coldbloods formed the most robust groups, whereas the Schleswig Draught Horse was the most distinct cold-blooded breed (Fig.). Further stable clusters are formed by the Arabian and Hanoverian, and by the Sorraia Horse and Exmoor Pony. The marker set developed was able to correctly assign randomly chosen draught horses from Germany with an accuracy of ninety-nine per cent (Table 2). 
Table 1

Chromosomal location, total number and range of observed alleles, amplification parameters, average heterozygosity $\left(\mathrm{H}_{\mathrm{S}}, \mathrm{H}_{\mathrm{T}}\right)$, and coefficient of differentiation $\left(\mathrm{G}_{\mathrm{ST}}\right)$ for 31 microsatellite loci; exponent letters indicate multiplex PCR (Chromosomale Lokalisation, Anzahl und Spannweite der gefundenen Allele, Parameter für die Amplifikation, mittlere Heterozygotie $\left(\mathrm{H}_{\mathrm{S}}, \mathrm{H}_{\mathrm{T}}\right)$ und Koeffizient für die Differenzierung $\left(\mathrm{G}_{\mathrm{ST}}\right)$ der 31 Mikrosatellitengenorte; die hochgestellten Buchstaben bezeichnen die PCR-Multiplexe)

\begin{tabular}{|c|c|c|c|c|c|c|c|c|c|c|c|}
\hline \multirow[b]{2}{*}{ ECA } & \multirow[b]{2}{*}{ Locus } & \multirow{2}{*}{$\begin{array}{l}\text { Primer } \\
(\mathrm{pmol}) \\
\end{array}$} & \multirow{2}{*}{$\begin{array}{l}\mathrm{T}_{\mathrm{M}} \\
{ }^{\circ} \mathrm{C}\end{array}$} & \multirow{2}{*}{$\begin{array}{l}\text { Size range } \\
\text { (bp) }\end{array}$} & \multirow{2}{*}{$\begin{array}{l}\text { No. of } \\
\text { alleles } \\
\end{array}$} & \multicolumn{3}{|c|}{ Heavy horses } & \multicolumn{3}{|c|}{ Other horses } \\
\hline & & & & & & $\mathrm{H}_{\mathrm{T}}$ & $\mathrm{H}_{\mathrm{S}}$ & $\mathrm{G}_{\mathrm{ST}}$ & $\mathrm{H}_{\mathrm{T}}$ & $\mathrm{H}_{\mathrm{S}}$ & $\mathrm{G}_{\mathrm{ST}}$ \\
\hline 1 & $\mathrm{HMS} 7^{\mathrm{a}}$ & 5.0 & 58 & $170-184$ & 8 & 0.644 & 0.619 & 0.039 & 0.818 & 0.688 & 0.158 \\
\hline 2 & $\mathrm{ASB} 17^{\mathrm{b}}$ & 6.0 & 60 & 89-131 & 19 & 0.850 & 0.805 & 0.053 & 0.842 & 0.712 & 0.155 \\
\hline 3 & $\mathrm{LEX} 07^{\mathrm{C}}$ & 8.0 & 55 & $186-202$ & 9 & 0.708 & 0.662 & 0.084 & 0.769 & 0.580 & 0.246 \\
\hline 4 & $\mathrm{LEX33}^{\mathrm{d}}$ & 10.0 & 55 & $178-204$ & 10 & 0.836 & 0.766 & 0.084 & 0.825 & 0.667 & 0.191 \\
\hline 5 & LEX34 ${ }^{\mathrm{C}}$ & 6.0 & 55 & $239-253$ & 7 & 0.675 & 0.633 & 0.061 & 0.712 & 0.506 & 0.206 \\
\hline 6 & COR070 & 9.0 & 62 & $263-299$ & 12 & 0.758 & 0.719 & 0.052 & 0.839 & 0.664 & 0.175 \\
\hline 7 & SGCV28 ${ }^{\mathrm{e}}$ & 1.0 & 62 & $149-165$ & 7 & 0.642 & 0.585 & 0.063 & 0.608 & 0.52 & 0.089 \\
\hline 8 & COR056 ${ }^{\mathrm{f}}$ & 8.0 & 58 & $180-212$ & 12 & 0.642 & 0.557 & 0.133 & 0.845 & 0.634 & 0.211 \\
\hline 9 & HMS03 $^{\mathrm{g}}$ & 1.0 & 58 & $149-171$ & 9 & 0.726 & 0.668 & 0.080 & 0.766 & 0.665 & 0.101 \\
\hline 10 & COR045 & 6.0 & 55 & $211-229$ & 10 & 0.778 & 0.751 & 0.035 & 0.82 & 0.711 & 0.108 \\
\hline 11 & $\mathrm{LEX}^{\mathrm{C}}{ }^{\mathrm{C}}$ & 3.0 & 55 & $146-170$ & 10 & 0.756 & 0.669 & 0.115 & 0.864 & 0.733 & 0.131 \\
\hline 12 & $\mathrm{COR}_{058^{\mathrm{a}}}$ & 8.0 & 58 & $206-230$ & 12 & 0.826 & 0.798 & 0.033 & 0.894 & 0.742 & 0.152 \\
\hline 13 & COR069 & 5.0 & 58 & 259-259 & 10 & 0.814 & 0.784 & 0.036 & 0.783 & 0.648 & 0.135 \\
\hline 14 & VHL209 & 8.0 & 58 & $83-97$ & 8 & 0.759 & 0.685 & 0.139 & 0.718 & 0.556 & 0.162 \\
\hline 15 & HTG06 $^{\mathrm{d}}$ & 1.0 & 55 & 82-104 & 8 & 0.317 & 0.296 & 0.066 & 0.718 & 0.556 & 0.162 \\
\hline 16 & $\mathrm{HTG}^{\mathrm{c}}$ & 6.0 & 55 & $114-128$ & 7 & 0.665 & 0.645 & 0.030 & 0.664 & 0.477 & 0.186 \\
\hline 17 & $\mathrm{COR} 007^{\mathrm{f}}$ & 4.0 & 58 & $154-182$ & 10 & 0.812 & 0.705 & 0.123 & 0.828 & 0.656 & 0.172 \\
\hline 18 & TKY019 & 6.0 & 55 & $144-164$ & 8 & 0.840 & 0.797 & 0.051 & 0.778 & 0.567 & 0.211 \\
\hline 19 & $\mathrm{LEX}^{\mathrm{d}}{ }^{\mathrm{d}}$ & 6.0 & 55 & $234-272$ & 12 & 0.738 & 0.707 & 0.042 & 0.806 & 0.605 & 0.201 \\
\hline 20 & UM11 ${ }^{\mathrm{h}}$ & 2.0 & 58 & $160-180$ & 15 & 0.700 & 0.678 & 0.032 & 0.808 & 0.684 & 0.124 \\
\hline 21 & SGCV16 & 10.0 & 55 & $140-192$ & 10 & 0.707 & 0.692 & 0.021 & 0.758 & 0.581 & 0.177 \\
\hline 22 & $\mathrm{COR}_{022}{ }^{\mathrm{f}}$ & 6.0 & 58 & $256-264$ & 4 & 0.574 & 0.550 & 0.042 & 0.723 & 0.565 & 0.159 \\
\hline 23 & LEX63 $^{\mathrm{i}}$ & 8.0 & 55 & $222-250$ & 10 & 0.755 & 0.694 & 0.081 & 0.843 & 0.578 & 0.265 \\
\hline 24 & COR024 & 5.0 & 58 & $205-219$ & 8 & 0.817 & 0.749 & 0.083 & 0.835 & 0.678 & 0.157 \\
\hline 25 & COR018 & 1.5 & 58 & $253-277$ & 9 & 0.707 & 0.650 & 0.080 & 0.793 & 0.608 & 0.186 \\
\hline 26 & $\mathrm{COR} 71^{\mathrm{k}}$ & 8.0 & 58 & $180-208$ & 12 & 0.699 & 0.665 & 0.050 & 0.779 & 0.549 & 0.23 \\
\hline 27 & COR017 & 1.5 & 58 & $235-255$ & 9 & 0.616 & 0.594 & 0.034 & 0.779 & 0.566 & 0.213 \\
\hline 28 & UCDEQ425 ${ }^{\mathrm{i}}$ & 8.0 & 55 & $227-245$ & 10 & 0.720 & 0.677 & 0.059 & 0.775 & 0.567 & 0.208 \\
\hline 29 & $\mathrm{COR}_{082^{\mathrm{f}}}$ & 6.0 & 58 & $198-232$ & 9 & 0.736 & 0.702 & 0.046 & 0.767 & 0.604 & 0.163 \\
\hline 30 & VHL20"g & 1.5 & 58 & 88-106 & 10 & 0.856 & 0.774 & 0.095 & 0.843 & 0.658 & 0.186 \\
\hline 31 & AHT34 $^{\mathrm{b}}$ & 6.0 & 60 & $121-143$ & 9 & 0.754 & 0.711 & 0.057 & 0.76 & 0.659 & 0.101 \\
\hline $\bar{x}$ & & & & & 9.77 & 0.676 & 0.682 & 0.116 & 0.785 & 0.620 & 0.212 \\
\hline$\pm \mathrm{SD}$ & & & & & \pm 2.67 & \pm 0.190 & \pm 0.102 & \pm 0.202 & \pm 0.061 & \pm 0.068 & \pm 0.054 \\
\hline
\end{tabular}

The evolution of today's horse breeds

Considering the fact that human populations from central Asia have contributed genetic material to northern European populations, BJØRNSTAD et al. (2003) proposed that it is likely that these people also had livestock with them for food and transportation; in this way eastern genes could also have dispersed to northern European horse populations. A comparison of the information obtained by BJØRNSTAD et al. (2001) to microsatellite data from Mongolian native horses 
revealed close associations between the Mongolian native horse and northern European breeds. In contrast, genetic distances were noticeably larger between the northern European breeds and standardbred/thoroughbred horses, which represent a southern source of horses. Thus, BJØRNSTAD et al. (2003) suggested that contributions of genetic material from eastern horses to northern European populations were likely.

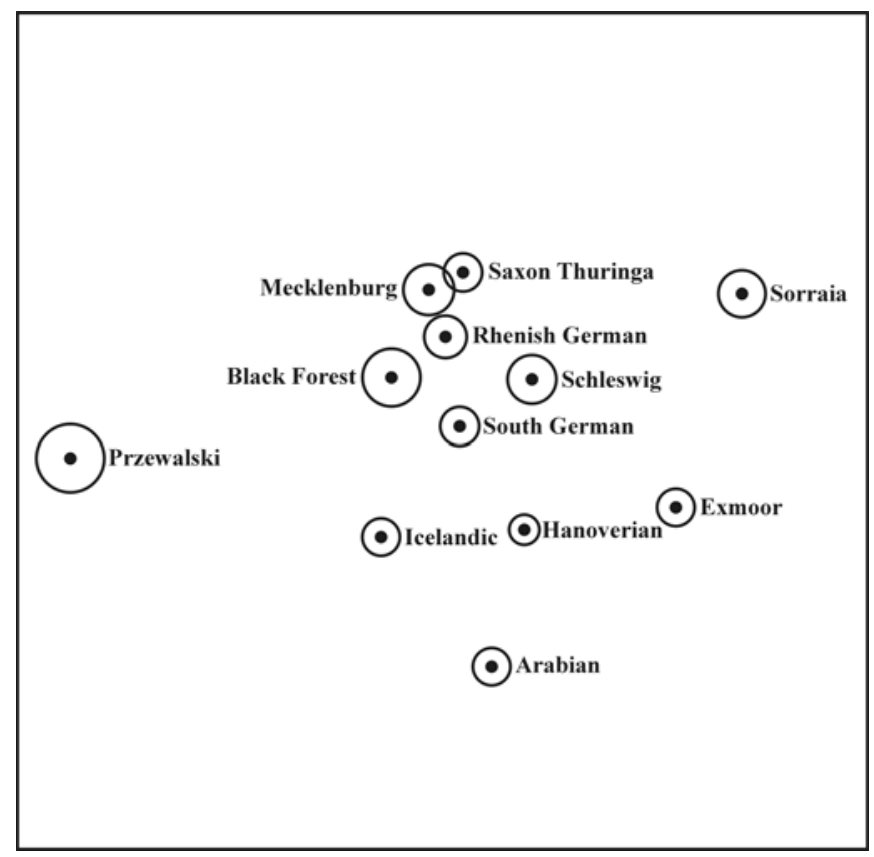

Fig.: Two dimensional presentation of Cavalli-Sforza genetic distances $\left(D_{C}\right)$ of 12 horse breeds with presentation of the variation for each breed. Circles represent 95\% of the variation observed (Zweidimensionale Darstellung der genetischen Distanz nach Cavalli-Sforza $\left(D_{C}\right)$ für 12 Pferderassen einschließlich deren Schätzvarianz. Die Kreise stellen 95\% der Varianz der Schätzung dar)

A rapidly evolving system with high mutational rate is needed for further evaluation of the evolution and domestication of horse breeds. These requirements are fulfilled in the genome of mitochondrial DNA (mtDNA), since its D-loop region is highly variable and evolves extremely rapidly compared with nuclear DNA (AQUADRO and GREENBERG, 1983). MtDNA is a small plasmid with less than $20 \mathrm{~kb}$ located in the mitochondrial organelle. The control-region mtDNA is a powerful tool to track genetic geographic patterns of diversity and phylogenetic structures, recent demographic expansions, genetic drift and hybridization. Advantages of mtDNA over microsatellites are that the mitochondrial genome is exclusively maternally inherited, haploid, and does not undergo recombination. Thus, the individuals from one matriline (dam line) are assumed to share one mtDNA haplotype. Moreover, the control region of mtDNA (D-loop) provides a highly informative tool for matrilineal relationship studies within breeds to detect their differentiation and to refer to different founder mares. The methods for assessing genetic diversity are similar to those for microsatellites and are discussed in detail by HOLDER and LEWIS (2003). The drawbacks of mtDNA analyses are that they cannot detect gene flows from males and the overall genomic diversity because mtDNA behaves like a single haplotype of extra-nuclear DNA. The horse mtDNA sequence was determined by XU and ÁRNÁSON (1994), who demonstrated that the length of the D-loop varied due to the presence of variable numbers of repeats of eight basepairs (bp) in the large conserved 
central sequence block of the control region. The number of repeats differed between 2 and 29 copies, although the majority was in the range of 22 to 27.

Table 2

Breed assignment test results from 12 horse breeds using genotype information from 31 microsatellite loci (upper part of the table, $\mathrm{P}<0.05$ ) and from newly analysed "anonymous" heavy draught horses (lower part of the table, $\mathrm{P}<0.001$ ) (Ergebnisse der Rassenzuordnungstests für 12 Pferderassen unter Verwendung von 31 Mikrosatellitenmarkergenorten (oberer Teil der Tabelle, $\mathrm{P}<0,05$ ) und für neu analysierte "anonyme" Kaltblutpferde (unterer Teil der Tabelle, $\mathrm{P}<0,001$ )

\begin{tabular}{|c|c|c|c|c|c|c|c|c|c|c|c|c|c|c|c|c|}
\hline Breed & & $\mathrm{N}^{*}$ & $\mathrm{SG}$ & RG & $\mathrm{MB}$ & ST & $\mathrm{BF}$ & SL & HAN & ICE & ARA & SO & PRZ & EX & none & $\begin{array}{l}\text { Misassigned } \\
\text { to }\end{array}$ \\
\hline \multirow[t]{2}{*}{$\overline{S G}$} & $\bar{I}$ & 45 & 43 & 1 & - & - & - & - & - & - & - & - & - & - & 2 & - \\
\hline & II & & 44 & 1 & & & & & & & & & & & & RG \\
\hline \multirow[t]{2}{*}{ RG } & I & 45 & 1 & 44 & 4 & 4 & - & - & - & - & - & - & - & - & 1 & - \\
\hline & II & & & 45 & & & & & & & & & & & & \\
\hline \multirow[t]{2}{*}{ MB } & I & 22 & - & 5 & 22 & 11 & - & - & - & - & - & - & - & - & - & - \\
\hline & II & & & & 21 & 1 & & & & & & & & & & $\mathrm{ST}$ \\
\hline \multirow[t]{2}{*}{ ST } & I & 23 & 1 & 9 & 14 & 23 & - & - & 1 & - & - & - & - & - & - & - \\
\hline & II & & & & & 23 & & & & & & & & & & \\
\hline \multirow[t]{2}{*}{$\mathrm{BF}$} & I & 45 & 2 & 1 & - & - & 42 & - & - & - & - & - & - & - & 3 & - \\
\hline & II & & & & & & 45 & & & & & & & & & \\
\hline \multirow[t]{2}{*}{ SL } & I & 45 & 1 & - & - & 1 & - & 44 & - & - & - & - & - & - & 1 & - \\
\hline & II & & & & & & & 45 & & & & & & & & \\
\hline \multirow[t]{2}{*}{ HAN } & I & 47 & - & - & - & - & - & - & 46 & - & - & - & - & - & 1 & - \\
\hline & II & & & & & & & & 47 & & & & & & & \\
\hline \multirow{2}{*}{ ICE } & I & 45 & - & - & - & - & - & - & - & 45 & - & - & - & - & - & - \\
\hline & II & & & & & & & & & 45 & & & & & & \\
\hline \multirow[t]{2}{*}{ ARA } & I & 26 & - & - & - & - & - & - & 3 & - & 24 & - & - & - & 2 & - \\
\hline & II & & & & & & & & & & 26 & & & & & \\
\hline \multirow[t]{2}{*}{ SO } & I & 23 & - & - & - & - & - & - & - & - & - & 23 & - & - & - & - \\
\hline & II & & & & & & & & & & & 23 & & & & \\
\hline \multirow[t]{2}{*}{ PRZ } & I & 18 & - & - & - & - & - & - & - & - & - & - & 20 & - & - & - \\
\hline & II & & & & & & & & & & & & 20 & & & \\
\hline \multirow[t]{2}{*}{$\mathrm{EX}$} & I & 20 & - & - & - & - & - & - & - & - & - & - & - & 18 & 2 & - \\
\hline & II & & & & & & & & & & & & & 20 & & \\
\hline \multirow{2}{*}{\multicolumn{2}{|c|}{$\begin{array}{l}\text { "Anonymous" } \\
\text { heavy horses }\end{array}$}} & & & & & & & & & & & & & & & Misassigned \\
\hline & & $\mathrm{N}^{*}$ & SG & RG & MB & $\mathrm{ST}$ & $\mathrm{BF}$ & SL & HAN & ICE & ARA & SO & PRZ & $\mathrm{EX}$ & none & to \\
\hline \multirow[t]{2}{*}{ SG } & I & 5 & 5 & - & - & - & - & - & - & - & - & - & - & - & - & - \\
\hline & II & & 5 & & & & & & & & & & & & & \\
\hline \multirow[t]{2}{*}{ RG } & I & 2 & - & 1 & - & 1 & - & - & - & - & - & - & - & - & 1 & - \\
\hline & II & & & 1 & & & & & & & & & & & & ST \\
\hline \multirow[t]{2}{*}{ MB } & I & 2 & - & 1 & 1 & 1 & 1 & - & - & - & - & - & - & - & 1 & - \\
\hline & II & & & & 2 & & & & & & & & & & & \\
\hline \multirow[t]{2}{*}{ ST } & I & 2 & - & 1 & 1 & 1 & - & - & - & - & - & - & - & - & 1 & - \\
\hline & II & & & & & 2 & & & & & & & & & & \\
\hline \multirow[t]{2}{*}{$\mathrm{BF}$} & I & 5 & 1 & 1 & 1 & - & 5 & - & - & - & - & - & - & - & - & - \\
\hline & II & & & & & & 5 & & & & & & & & & \\
\hline \multirow[t]{2}{*}{ SL } & I & 4 & 2 & - & - & - & - & 3 & - & - & - & - & - & - & 1 & - \\
\hline & II & & & & & & & 3 & & & & & & & & SG \\
\hline
\end{tabular}

*If horses were assigned to more than one population, the sum of each row may be greater than the number of horses analyzed.

Numbers in the first row (I) represent individuals assigned to a breed with the "exclusion-simulation" approach, while numbers in the second row (II) represent the number of individuals assigned using the "direct” approach (without a P-value).

SG: South German Coldblood, RG: Rhenish German Draught Horse, ST: Saxon Thuringa Coldblood, MB: Mecklenburg Coldblood, BF: Black Forest Horse, SL: Schleswig Draught Horse, HAN: Hanoverian Warmblood, ARA: Arabian, ICE: Icelandic Horse, EX: Exmoor Pony, SO: Sorraia Horse, PRZ: Przewalski’s Horse.

\section{MtDNA diversity in horses}

ISHIDA et al. (1995) were the first to use direct sequencing of the most variable region of the D-loop to estimate phylogenetic relationships within the genus Equus. They estimated the evolutionary rate of the studied region to be between 2 and $4 \times 10^{-8}$ 
per site per year and provided new information particularly concerning the evolution of domestic and Przewalski's Horses. They concluded that the lineage of the Przewalski's wild horse is not located at the deepest branching among the E. caballus sequences in the neighbor-joining trees they constructed. The observed topology of the trees is clearly inconsistent with an origin of the domestic horse from Przewalski's Horse, although the Przewalski's Horse was shown to be within the genetic variation of the domestic horses, suggesting that the chromosome number change occurred rather recently. OAKENFULL and RYDER (1998) investigated the variation in the mitochondrial control region and 12S rRNA in all four extant mitochondrial lineages of the Przewalski's Horse, none of which is descended from domestic/Przewalski's hybrids or domestic horse founders. Only two different sequences were found, one of which corresponds to that of ISHIDA et al. (1995). Thus, variation was found to be very low, despite individuals who apparently originated from three distinct geographical regions. The other sequence differed from the first, but both were certainly more similar to the published sequences of three thoroughbreds and of a Mongolian Horse than to other equids. KIM et al. (1999) sequenced the D-loop region to test the hypothesis that horses inhabiting the island of Cheju in Korea are descendants of Mongolian Horses. Since the sequences varied considerably within the horse breeds, and since Cheju Horses clustered with Mongolian Horses as well as with horses from other distant breeds, the authors proposed that the horses on Cheju island were of mixed origin in their maternal lineage, and that they may have been present on the island and the object of trade before the Mongolian introduction. In a follow-up study YANG et al. (2002) found 17 distinct haplotypes in almost all Cheju Horses currently inhabiting the island.

Another phylogenetic analysis was performed by MIROL et al. (2002), who investigated the relationship between Argentinean Creole and Spanish Horses by direct sequencing and SSCP analysis. As expected from the results of the other studies described above, a very high variability was found both between and within breeds, but no clear relationship was observed in the phylogenetic trees between the South American and any of the other horses analysed.

\section{Matriline variability within breeds}

Mitochondrial D-loop sequence variation among maternal lineages of the Lipizzan, Arabian, and thoroughbred horses was determined by KAVAR et al. (1999, 2002), BOWLING et al. (2000), and HILL et al. (2002), respectively. Sixteen maternal lines of the Lipizzan horse were grouped into 13 distinct mitochondrial haplotypes with stable inheritance, and no sequence variation was observed that was potentially attributable to mutation within maternal lines. Historical data about the multiple origin of the Lipizzan breed was supported by the phylogenetic analysis, which produced a dendrogram with three separate branches. Sequencing of 212 Lipizzans revealed 37 haplotypes (KAVAR et al., 2002). A comparison of these sequences to 136 sequences of domestic and wild horses from GenBank showed a clustering of Lipizzan haplotypes in the majority of haplotype subgroups present in other domestic horses. These findings correspond to historical data, according to which numerous Lipizzan maternal lines originating from founder mares of different breeds were established during the breed's history. The authors proposed that domestic horses could therefore have arisen either from a single large population or from several populations assuming 
that strong migrations occurred during the early phase of domestication. A parentage disagreement was found for at least $11 \%$ of the Lipizzans. The Arabian Horses in the USA were traced in the maternal line to 34 mares showing 27 haplotypes (BOWLING et al., 2000). They observed single base differences within two lines which were interpreted as representing alternative fixations of past heteroplasmy, calling into question the traditional assumption that Arabian Horses of the same strain necessarily share a common maternal ancestry. Seventeen haplotypes were found in 19 of the most common matrilineal female families of the thoroughbred horse (HILL et al., 2002). Using both SSCP analysis and direct sequence analysis, HILL et al. (2002) compared thoroughbred families to 13 other diverse horse populations, revealing no significant differences in variation and suggesting a non-random partitioning of diversity among geographically diverse horse populations. Common descent was found to be inconsistent in almost half of the female families, probably due to confusions of mares at the foundation stages. Another analysis of maternal line variation was performed by LUís et al. (2002) in the Sorraia Horse breed. Tracing back the maternal lineages revealed that only two different lines have survived and therefore only two haplotypes, only one of which is present in the German population.

How and when were horses domesticated?

According to archaeological evidence, the horse was domesticated many times around 6,000 years ago in more northerly latitudes of the broad region of the Eurasian steppe, where wild horses would have been captured and selectively bred for desirable characteristics (CLUTTON-BROCK, 1999). The wild horses had such a wide geographic range that once wild horses had been domesticated at one location, they could not spread so rapidly that further independent domestications were preempted, but there was enough time for independent domestications at other locations (DIAMOND, 2002). And the earliest known clay figurine of a domestic horse dates back to 2300 BC. It was found about $300 \mathrm{~km}$ northeast of Damascus (BOWER, 1993). The horse is apparently the most recently domesticated major livestock species. But since a high level of mtDNA diversity was observed in all investigated domestic horse populations, the question arises as to the origin of this amount of diversity and how horses were in fact domesticated. It has been the main objective of recent mtDNA studies to answer these questions. The first approach was that of LISTER et al. (1998), who examined sequence data of the mtDNA control region from 29 individuals, including Przewalski's Horse as representative of a wild horse population, and 14 domestic breeds. Since LISTER et al. (1998) found virtual genetic constancy within the Przewalski's Horse and wide variation within domestic breeds, they concluded that domestication must not have arisen from a single, local population, but from wild stock distributed over a moderately extensive geographical region. To provide a more conclusive answer, VILÀ et al. (2001) augmented their modern mtDNA with additional results on ancient specimens from archaeological sites in Sweden and late Pleistocene deposits from Alaska as wild horse representatives, and with microsatellite DNA sequences. Since VILÀ et al. (2001) also found limited diversity in these ancient populations, they essentially drew the same conclusions as LISTER et al. (1998). However, the microsatellite data suggested that females have contributed more to the genetic diversity of horse breeds than males, perhaps due to the bias towards females in trade and breeding, which is consistent with traditional breeding practices by which 
a single male is bred with multiple females. On the basis of an average rate of equid mtDNA sequence divergence of $4.1 \%$ or $8.1 \%$ per million years, they estimated that modern horse lineages coalesced about 0.32 or 0.63 million years ago (MA), which gives enough time for the evolution of numerous matrilines until the beginning of domestication. JANSEN et al. (2002) went even further, as they investigated mtDNA clusters in relation to geographic area and breed. They sequenced a total of 318 horses from 25 oriental and European breeds which were combined with data from GenBank to a total of 652 sequences covering Europe, Morocco, and parts of central and eastern Asia. Most of the 93 different haplotypes grouped into 17 distinct phylogenetic clusters, many corresponding to breeds or geographic areas. Instead of two different mtDNA haplotypes in the Przewalski's Horse (OAKENFULL and RYDER, 1998), JANSEN et al. (2002) found three, which, however, were restricted to one mtDNA cluster distinct from the domestic horse breeds. The low diversity of mtDNA of the Przewalski's Horse and its position in a side-branch of the phylogenetic network suggest that the Przewalski's Horse is not ancestral to domestic horses. Surprisingly, the Sorraia Horse did not cluster with the modern Iberian horse breeds, which may be due to the recent bottleneck, after which only two Sorraia mtDNA haplotypes survived.

JANSEN et al. (2002) estimated a minimum mutation rate of one mutation per 100,000 years and a maximum rate of one mutation per 350,000 years, respectively. Thus, their results suggested that approximately 300,000 years represents the latest possible date for the first caballine horse, which is similar to the date estimated by VILÀ et al. (2001).

The number of wild mares contributing mtDNA to domestic horses was determined by considering the mtDNA mutation rate together with the archaeological time frame for domestication. This estimation revealed that at least 77 successfully breeding mares must have been recruited from the wild.

The overall conclusion drawn from the three studies is that several distinct horse populations were involved in the domestication of the horse and the horse has been domesticated on numerous independent occasions. VILÀ et al. (2001) concluded that the widespread utilisation of horses occurred primarily through the transfer of technology for capturing, taming, and rearing animals caught in the wild, since the export of domesticated horses would have resulted in a more limited diversity of matrilines. In contrast, JANSEN et al. (2002) suggested that both the knowledge of domesticating and breeding horses and the first domesticated horses themselves would have spread, forming the regional mtDNA clusters.

\section{Conclusions}

Diversity studies provide information on variation between and within breeds at the DNA level. But since only few microsatellite loci are used in more than one equine study, it is difficult to make interbreed comparisons with published data. CHECA et al. (1998) and BJØRNSTAD et al. (2003) showed that it is possible to compare populations of different studies when using the same microsatellite loci.

Thus, the advantage of a microsatellite data set especially defined for horse genetic diversity studies as has already been compiled for cattle, chicken, sheep, and swine by the FAO would make it possible to standardise results and make them comparable with each other. 
The comparison of the different phylogenetic studies based on mtDNA revealed high haplotype variations even within individual breeds, so that the origin of single breeds is hard to determine. However, when large data sets for many different breeds are analysed, mtDNA studies deepen our understanding of the process of horse evolution and domestication. Furthermore, molecular data may be used as measures to maintain sufficient genetic variation within and between breeds and as aids to implement management strategies for breed conservation. At present, molecular markers only comprise a part of the variation of the phenotypes. With the increasing publication of genome sequences, expressed sequence tags and causative mutations for phenotypic traits the availability of polymorphic molecular markers will rapidly increase and offer new and exciting approaches to understand and maintain genetic diversity in horse populations.

\section{References}

AQUADRO, C.; GREENBERG, B.D.: Human mitochondrial DNA variation and evolution: analysis of nucleotide sequences from seven individuals. Genetics 103 (1983), 287-312

BENIRSCHKE, K.; MALOUF, N.; LOW, R.J.; HECK, H.: Chromosome complement: differences between Equus caballus and Equus przewalskii, Poliakoff. Science 148 (1965), 382-383

BINNS, M.; SWINEBURNE, J.; BREEN, M.:

Molecular genetics of the horse. In: The Genetics of the Horse. BOWLING, A.T.; RUVINSKY, A. (Eds): (1999), pp. 109-118. Wallingford, UK: CABI Publishing

BJØRNSTAD, G.; GUNBY, E., RØED, K.H.:

Genetic structure of Norwegian horse breeds. J. Anim. Breed. Genet. 117 (2000), 307-317

BJØRNSTAD, G.; NILSEN, Ø.; RØED, K.H.:

BÖKÖNYI, S.: Genetic relationship between Mongolian and Norwegian horses? Anim. Genet. 34 (2003), 55-58

History of horse domestication. Animal Genetic Resources Information 6 (1987), 27-32

BOUMAN, I.; BOUMAN, J.:

The history of Przewalski's Horse. In: Przewalski's Horse - The history and biology of an endangered species. BOYD L.; HOUPT K.A. (Eds): (1994), 5-38. Albany, NY, USA: State University of New York Press

BOWER, B.:

Ancient figurine lifts horses’ profile. Science News 143 (1993), 22

BOWLING, A.T.; DEL VALLE, A.; BOWLING, M.:

A pedigree-based study of mitochondrial D-loop DNA sequence variation among Arabian horses. Anim. Genet. 31 (2000), 1-7

BREEN, M.; DOWNS, P.; IRVIN, Z.; BELL, K.: Intrageneric amplification of horse microsatellite markers with emphasis on the Przewalski's horse (E. przewalskii). Anim. Genet. 25 (1994), 401-405

CAÑON, J.; CHECA, M.L.; CARLEOS, C.; VEGA-PLA, J.L.; VALLEJO, M.; DUNNER, S.:

The genetic structure of Spanish Celtic horse breeds inferred from microsatellite data. Anim. Genet. 31 (2000), 39-48

CAVALLI-SFORZA L.L.; EDWARDS A.W.F.:

Phylogenetic analysis: models and estimation procedures. Am. J. Hum. Genet. 19 (1967), 233-257.

CHECA, M.L.; DUNNER, S.; MARTIN, J.P.; VEGA, J.L.; CAÑON, J.:

A note on the characterization of a small Celtic pony breed. J. Anim. Breed. Genet. 115 (1998), 157-163

CLUTTON-BROCK, J.:

A natural history of domesticated mammals. Cambridge: Cambridge University Press (1999)

CORNUET, J.M.; PIRY, S.; LUIKART, G.; ESTOUP, A.; SOLIGNAC, M.:

New methods employing multilocus genotypes to select or exclude populations as origins of individuals. Genetics 153 (1999), 1989-2000

DIAMOND, J.:

Evolution, consequences and future of plant and animal domestication. Nature 418 (2002), 700-707

DIERINGER, D.; SCHLÖTTERER, C.: 
Microsatellite analyser (MSA): a platform independent analysis tool for large microsatellite data sets. Mol. Ecol. Not. 3 (2003), 167-169

DISTL, O.; WREDE, J.:

EAAP-Animal Genetic Data Bank (2002). Institut für Tierzucht und Vererbungsforschung, Tierärztliche Hochschule Hannover. http://www.tiho-hannover.de/einricht/zucht/ eaap/index.htm.

EDING, J.H.; LAVAL, G.:

Measuring genetic uniqueness in livestock. In: Genebanks and the conservation of farm animal genetic resources. Oldenbroek, J.K. (Eds) (1999), 33-58. DLO Institute for Animal Science and Health, Lelystad, The Netherlands

ELLEGREN, H.; JOHANSSON, M.; SANDEBRG, K.; ANDERSSON, L.:

Cloning of highly polymorphic microsatellites in the horse. Anim. Genet. 23 (1992), 133-142

FELSENSTEIN, J.: FREY, O.

PHYLIP - Phylogeny Inference Package (Version 3.2). Cladistics 5 (1989), 164-166

Baden-Württembergs Pferde. (1984), Stuttgart, Germany: Franckh’sche Verlagshandlung.

GROVES, C.P.:

Morphology, habitat, and taxonomy. In Przewalski's horse - The history and biology of an endangered species. BOYD L.; HOUPT K.A. (Eds): (1994), 39-60. Albany, NY, USA: State University of New York Press

GOUDET, J.:

FSTAT, Version 1.2, a computer program to calculate F-Statistics. J. Hered. 86 (1995), 485-486

GUO, S.W.; THOMPSON, E.A.:

Performing the exact test of Hardy-Weinberg proportions for multiple alleles. Biometrics 48 (1992), 361-372

HILL E.W.; BRADLEY, D.G.; AL-BARODY, M.; ERTUGRUL, O.; SPLAN, R.K.; ZAKHAROV, I.; CUNNINGHAM, E.P.:

History and integrity of thoroughbred dam lines revealed in equine mtDNA variation. Anim. Genet. 33 (2002), 287-294

HOLDER, M.; LEWIS, P.:

HOLM, S.: Phylogeny estimation: traditional and bayesian approaches. Nat. Rev. 4 (2003), 275-284

A simple sequentially rejective multiple test procedure. Scand. J. Stat. 6 (1979), 65-75

ISHIDA, N.; HASEGAWA, T.; TAKEDA, K.; SAKAGAMI, M.; ONISHI, A.; INUMARU, S.; KOMATSU, M.; MUKOYAMA, H.:

Polymorphic sequence in the D-loop region of equine mitochondrial DNA. Anim. Genet. 25 (1994a), 215-221

ISHIDA, N.; HIRANO, T.; MUKOYAMA, H.:

Detection of aberrant alleles in the D-loop region of equine mitochondrial DNA by single strand conformation polymorphism (SSCP) analysis. Anim. Genet. 25 (1994b), 287

ISHIDA, N.; OYUNSUREN, T.; MASHIMA, S.; MUKOYAMA, H.; SAITOU, N.:

Mitochondrial DNA sequences of various species of the genus equus with special reference to the phylogenetic relationship between Przewalski’s wild horse and domestic horse. J. Mol. Evol. 41 (1995), 180-188

ISHIDA, N.; HASEGAWA, T.; OYUNSUREN, T.; MUKOYAMA, H.:

PCR-RFLP analysis of the cytochrome b gene in horse mitochondrial DNA. Anim. Genet. 27 (1996), 359-363

JANSEN, T.; FORSTER, P.; LEVINE, M.A.; OELKE, H.; HURLES, M.; RENFREW, C.; WEBER, J.; OLEK, K.:

Mitochondrial DNA and the origins of the domestic horse. Proc. Nat. Acad. Sci. USA 99 (2002), $10905-10910$

KARNBAUM, B.:

Das Süddeutsche Kaltblut in Bayern. Kempten, Germany (1997): AVA Verlag Allgäu

KAVAR, T.; HABE, F.; BREM, G.; DOVC, P.:

Mitochondrial D-loop sequence variation among the 16 maternal lines of the Lipizzan horse breed. Anim. Genet. 30, (1999), 423-430

KAVAR, T.; BREM, G.; HABE, F.; SÖLKNER, J.; DOVC, P.:

History of Lipizzan horse maternal lines as revealed by mtDNA analysis. Gen. Sel. Evol. 34 (2002), 635-648

KELLY. L.; POSTIGLIONI, A.; DE ANDRÉS, D.F.; VEGA-PLÁ, J.L.; GAGLIARDI, R.; BIAGETTI, R.; FRANCO, J.:

Genetic characterization of the Urugayan Creole horse and analysis of relationships among horse breeds. Res. Vet. Sci. 72 (2002), 69-73 
KIM, K.-I.; YANG, Y.-H.; LEE, S.-S.; PARK, C.; MA, R.; BOUZAT, J.L.; LEWIN, H.A.:

Phylogenetic relationships of Cheju horses to other horse breeds as determined by mtDNA D-loop sequence polymorphism. Anim. Genet. 30 (1999), 102-108

LISTER, A.M.; KADWELL, M.; KAAGAN, L.M.; JORDAN, W.C.; RICHARDS, M.B.; STANLEY, H.F.; Ancient and modern DNA in a study of horse domestication. Ancient Biomolecules 2 (1998), 267-280

LUÍS, C.; BASTOS-SILVEIRA, C. ; COTHRAN, E.G. ; OOM, M.M. :

Variation in the mitochondrial control region sequence between the two maternal lines of the Sorraia horse breed. Genet. Mol. Biol. 25 (2002), 309-311

MARKLUND, L.; ELLEGREN, H.; ERIKSSON, S.; SANDBERG, K.; ANDERSSON, L.:

Parentage testing and linkage analysis in the horse using a set of highly polymorphic horse microsatellites. Anim. Genet. 25 (1994), 19-23

MARKLUND, S.; CHAUDHARY, R.; MARKLUND, L.; SANDBERG, K.; ANDERSSON, L. Extensive mtDNA diversity in horses revealed by PCR-SSCP analysis. Anim. Genet. 26 (1995), 193196

NEI, M.:

Analysis of gene diversity in subdivided populations. Proc. Nat. Acad. Sci. USA 70 (1973), 3321-3323

NISSEN, J.:

Enzyklopädie der Pferderassen, Europa Band 1. Frankh-Kosmos Verlag, Stuttgart, Germany (1997)

NISSEN, J.:

Enzyklopädie der Pferderassen, Europa Band 2. Frankh-Kosmos Verlag, Stuttgart, Germany (1998)

NISSEN, J.:

Enzyklopädie der Pferderassen, Europa Band 3. Frankh-Kosmos Verlag, Stuttgart, Germany (1999)

OAKENFULL E.A.; RYDER, O.A.:

Mitochondrial control region and 12 S rRNA variation in Przewalski's horse (Equus przewalskii). Anim. Genet. 29 (1998), 456-459

OOM, M.M.; COTHRAN E.G.:

The genetic variation of an endangered breed: the Sorraia horse. Anim. Genet. 27 (Suppl. 2) (1994), 35

OOM, M.M.; LUÍS C.:

Conservation genetics meeting, (2001) Lausanne, Switzerland

RAYMOND, M.; ROUSSET, F.:

GENEPOP (version 1.2): population genetics software for exact tests and ecumenicism. J. Hered. 86 (1995), 248-249

RYDER, O.A.; EPEL, N.C.; BENIRSCHKE, K.:

Chromosome banding studies of the equidae. Cytogenet. Cell Genet. 20 (1978), 323-350

RYDER, O.A.:

Przewalski's horse: prospects for reintroduction into the wild. Cons. Biol. 7 (1993), 13-15

SAMBRAUS, H.H.:

Farbatlas Nutztierrassen. 6th edition, Verlag Eugen Ulmer, Stuttgart, Germany (2001)

SCHARNHÖLZ, R.:

Kaltblutpferde. Starke-Pferde Verlag, Lemgo, Germany (2002)

SHIUE, Y.-L.; BICKEL, L.A.; CAETANO, A.R.; MILON, L.V.; CLARK, R.S.; EGGLESTON, M.L.; MICHELMORE, R.; BAILEY, E.; GUERIN, G.; GODARD, S.; MICKELSON, J.R.; VALBERG, S.J.; MURRAY, J.D.; BOWLING, A.T.:

A synteny map of the horse genome comprised of 240 microsatellite and RAPD markers. Anim. Genet. 30 (1999), 1-9

SPONENBERG, D.P.:

Genetic resources and their conservation. In: The Genetics of the Horse. BOWLING, A.T.; RUVINSKY, A. (eds): (2000), 387-410, Wallingford, UK: CABI Publishing

VILÀ, C.; LEONARD, J.A.; GÖTHERSTRÖM, A.; MARKLUND, S.; SANDBERG, K.; LIDÉN, K.; WAYNE, R.K.; ELLEGREN, H.:

VOLF, J.: Widespread origins of domestic horse lineages. Science 291, (2001), 474-477

Das Urwildpferd: Equus przewalskii. pp. (1996), 47-49; 4th edition, Heidelberg, Germany: Spektrum Akademischer Verlag, (Die neue Brehm-Bücherei; Bd. 249)

WANG, W.; LIU, A.; LIN, S.; LAN, H.; SU, B.; XIE, D.; SHI, L.:

Multiple genotypes of mitochondrial DNA within a horse population from a small region in Yunnan province of China. Biochem. Genet. 32 (1994), 371-378

\section{WEBER, M.:}

Stand und Weiterentwicklung der Schwarzwälder Kaltblutzucht in Baden-Württemberg zur Jahrhundertwende 2000/2001: Entwicklung der Kaltblutzucht seit 1947 bis heute. In: Festschrift zum 23. Tag des Schwarzwälder Pferdes. pp. (2001), 34-64 Titisee-Neustadt, Germany: Gemeinde St. Märgen, Druck \& Papier Berenbold 
XU, X.; ÁRNÁSON, Ú.:

The complete mitochondrial DNA sequence of the horse, Equus caballus: extensive heteroplasmy of the control region. Gene 148 (1994), 357-362

YANG, Y.H; KIM, K.I.; COTHRAN, E.G.; FLANNERY, A.R.:

Genetic diversity of Cheju horses (equus caballus) determined by using mitochondrial DNA D-loop polymorphism. Biochem. Genet. 40 (2002), 175-186

Received: 2004-07-07

Accepted: 2004-09-23

Author's address

KERSTIN S. ABERLE, Prof. Dr. OTTMAR DISTL*

Institute for Animal Breeding and Genetics

University of Veterinary Medicine Hannover

Bünteweg 17p

D-30559 Hannover

Germany

E-Mail:ottmar.distl@tiho-hannover.de

* Corresponding author 